\title{
Front Matter: Volume 7068
}

, "Front Matter: Volume 7068," Proc. SPIE 7068, Optical System Alignment and Tolerancing II, 706801 (25 September 2008); doi: 10.1117/12.812902

SPIE Event: Optical Engineering + Applications, 2008, San Diego, California, United SPIE. States 


\section{PROCEEDINGS OF SPIE}

\section{Optical System Alignment and Tolerancing II}

José M. Sasian

Richard N. Youngworth

Editors

10-11 August 2008

San Diego, California, USA

Sponsored and Published by

SPIE

Volume 7068 
The papers included in this volume were part of the technical conference cited on the cover and title page. Papers were selected and subject to review by the editors and conference program committee. Some conference presentations may not be available for publication. The papers published in these proceedings reflect the work and thoughts of the authors and are published herein as submitted. The publisher is not responsible for the validity of the information or for any outcomes resulting from reliance thereon.

Please use the following format to cite material from this book:

Author(s), "Title of Paper," in Optical System Alignment and Tolerancing II, edited by José M. Sasian, Richard N. Youngworth, Proceedings of SPIE Vol. 7068 (SPIE, Bellingham, WA, 2008) Article CID Number.

ISSN 0277-786X

ISBN 9780819472885

Published by

SPIE

P.O. Box 10, Bellingham, Washington 98227-0010 USA

Telephone +1 3606763290 (Pacific Time) · Fax +1 3606471445

SPIE.org

Copyright (C 2008, Society of Photo-Optical Instrumentation Engineers

Copying of material in this book for internal or personal use, or for the internal or personal use of specific clients, beyond the fair use provisions granted by the U.S. Copyright Law is authorized by SPIE subject to payment of copying fees. The Transactional Reporting Service base fee for this volume is $\$ 18.00$ per article (or portion thereof), which should be paid directly to the Copyright Clearance Center (CCC), 222 Rosewood Drive, Danvers, MA 01923. Payment may also be made electronically through CCC Online at copyright.com. Other copying for republication, resale, advertising or promotion, or any form of systematic or multiple reproduction of any material in this book is prohibited except with permission in writing from the publisher. The CCC fee code is $0277-786 \mathrm{X} / 08 / \$ 18.00$.

Printed in the United States of America.

Publication of record for individual papers is online in the SPIE Digital Library.

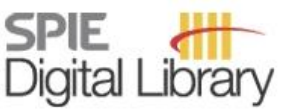

SPIEDigitallibrary.org

Paper Numbering: Proceedings of SPIE follow an e-First publication model, with papers published first online and then in print and on CD-ROM. Papers are published as they are submitted and meet publication criteria. A unique, consistent, permanent citation identifier (CID) number is assigned to each article at the time of the first publication. Utilization of CIDs allows articles to be fully citable as soon they are published online, and connects the same identifier to all online, print, and electronic versions of the publication. SPIE uses a six-digit CID article numbering system in which:

- The first four digits correspond to the SPIE volume number.

- The last two digits indicate publication order within the volume using a Base 36 numbering system employing both numerals and letters. These two-number sets start with 00, 01, 02, 03, 04, 05, $06,07,08,09,0 A, 0 B \ldots 0 Z$, followed by $10-12,20-2 Z$, etc.

The CID number appears on each page of the manuscript. The complete citation is used on the first page, and an abbreviated version on subsequent pages. Numbers in the index correspond to the last two digits of the six-digit CID number. 


\section{Contents}

vii Conference Committee
ix Introduction

SESSION 1 TOLERANCING OPTICAL SYSTEMS

706802 Probabilistic method for multiparameter tolerancing in illuminator design [7068-01]

S. Smirnov, E. Catey, ASML Wilton (United States)

706803 Tolerances don't lie...and stories of the Grand Canyon! (Invited Paper) [7068-02]

R. E. Fischer, OPTICS 1, Inc. (United States)

706804 Tolerancing and corner cases in optical simulation [7068-03]

R. P. Dahlgren, K. D. Pedrotti, Univ. of California/Santa Cruz (United States)

706807 The effect on tolerance distributing of an off-axis three mirror anastigmatic optical system with wavefront coding technology [7068-05]

F. Yan, Changchun Institute of Optics, Fine Mechanics and Physics (China) and Graduate School, Chinese Academy of Science (China); X. Zhang, Changchun Institute of Optics, Fine Mechanics and Physics (China)

\section{SESSION 2 ALIGNMENT METHODOLOGY AND THEORY}

706808 IR spectrometer using 90-degree off-axis parabolic mirrors [7068-06]

R. M. Malone, National Security Technologies, LLC (United States); D. H. Dolan, Sandia National Labs. (United States); R. G. Hacking, I. J. McKenna, National Security Technologies, LLC (United States)

7068 OA Alignment analysis of optical systems using derivative information [7068-08] C. Olson, L-3 Communications (United States); R. N. Youngworth, Light Capture, Inc. (United States)

7068 OB Line of sight methods of alignment [7068-09]

R. E. Parks, Optical Perspectives Group, LLC (United States) and College of Optical Sciences/The Univ. of Arizona (United States)

7068 OC A simple tool for alignment and wavefront testing: experimental results [7068-10] W. P. Kunn, Opt-E (United States)

\section{SESSION $3 \quad$ INSTRUMENT AND SYSTEM ALIGNMENT}

7068 OD Active alignment for the Large Binocular Telescope Bent-Gregorian focus: first results [7068-11]

A. Rakich, D. L. Miller, Large Binocular Telescope Observatory (United States) 
7068 OE Alignment induced aberration fields of next generation telescopes (Invited Paper) [7068-12]

T. Schmid, CREOL/Univ. of Central Florida (United States); K. Thompson, Optical Research Associates (United States); J. Rolland, CREOL/Univ. of Central Florida (United States)

7068 OF Optical metrology and alignment of the James Webb Space Telescope Integrated Science Instrument Module [7068-13]

J. A. Connelly, B. J. Bos, P. S. Davila, W. L. Eichhorn, B. J. Frey, J. G. Hagopian, J. E. Hylan, J. M. Marsh, D. B. McGuffey, NASA Goddard Space Flight Ctr. (United States); J. McMann, QinetiQ North America (United States); M. D. Nowak, R. G. Ohl, NASA Goddard Space Flight Ctr. (United States); K. W. Redman, QinetiQ North America (United States); D. Sabatke, Ball Aerospace \& Technologies Corp. (United States); H. P. Sampler, NASA Goddard Space Flight Ctr. (United States); J. Stock, SGT, Inc. (United States); J. Sullivan, Ball Aerospace \& Technologies Corp. (United States); G. W. Wenzel, QinetiQ North America (United States); G. A. Wright, NASA Goddard Space Flight Ctr. (United States); P. Young, Young Engineering Services (United States)

7068 OG Determination of wavefront measurement points for predicting full-field NIRCam wavefront performance [7068-14]

B. Herman, T. B. Andersen, P. F. Schweiger, Lockheed Martin Space Systems Co. (United States)

$7068 \mathrm{OH} \quad$ Assessment of NIRCam alignment tolerances by Monte Carlo simulations [7068-15] T. B. Andersen, P. F. Schweiger, Lockheed Martin Space Systems Co. (United States)

\section{SESSION 4 ALIGNMENT DEVICES, METROLOGY, AND FABRICATION}

7068 ol Cross-grating slit test with an interlacing tip-tilt alignment method [7068-16] C.-W. Liang, C.-F. Ou, National Central Univ. (Taiwan)

7068 OK Metrologically speaking [7068-18] M. E. Hansen, ASML Optics (United States)

$7068 \mathrm{OL}$ An alignment technique based on the speckle correlation properties of Fresnel transforming optical systems [7068-19]

J. E. Ward, Univ. College Dublin (Ireland); D. P. Kelly, National University of Ireland (Ireland); J. T. Sheridan, Univ. College Dublin (Ireland)

7068 OM Miniaturised optical encoder [7068-20]

J. Carr, Heriot-Watt Univ. (United Kingdom) and Renishaw plc (United Kingdom); M. P. Y. Desmulliez, Heriot-Watt Univ. (United Kingdom); N. Weston, D. McKendrick, G. Cunningham, G. McFarland, Renishaw plc (United Kingdom); W. Meredith, A. McKee, C. Langton, I. Eddie, CST Global Ltd (United Kingdom)

\section{POSTER SESSION}

706800 Closed-loop high-precision position control system with two modes [7068-22] C. Ge, Univ. of Electric and Scientific Technology of China (China) and Institute of Applied Electronics (China); G. Fan, Z. Huang, Z. Liu, Z. Li, J. Wu, M. Wan, X. Hu, Institute of Applied Electronics (China); Z. Liang, Univ. Of Electric and Scientific Technology of China (China) 
$7068 \mathrm{OP} \quad$ Misalignment parameters estimation in refractive optical systems [7068-23]

B. F. C. de Albuquerque, R. V. F. Lopes, H. K. Kuga, Instituto Nacional de Pesquisas Espaciais (Brazil); E. G. de Carvalho, L. C. Nakata Scaduto, M. A. Stefani, Opto Eletrônica S.A. (Brazil)

$70680 Q \quad$ Verification of the James Webb Space Telescope Integrated Science Instrument Module cryogenic structural alignment requirements via photogrammetry [7068-24]

M. Nowak, NASA Goddard Space Flight Ctr. (United States); P. Cleveland, Energy Solutions International, LLC (United States); A. Crane, Alliant Techsystems Inc. (United States);

P. Davila, A. Herrera, J. Hylan, NASA Goddard Space Flight Ctr. (United States); A. Liehr, Stinger Ghaffarian Technologies (United States); J. Marsh, R. Ohl, NASA Goddard Space Flight Ctr. (United States); K. Redman, QinetiQ Inc. (United States); H. Sampler, NASA Goddard Space Flight Ctr. (United States); J. Stock, Stinger Ghaffarian Technologies (United States); G. Wenzel, QinetiQ Inc. (United States); R. Woodruff, Lockheed Martin Space Systems Co. (United States); P. Young, Young Engineering Services, Inc. (United States)

Author Index 
Downloaded From: https://www.spiedigitallibrary.org/conference-proceedings-of-spie on 25 Apr 2023

Terms of Use: https://www.spiedigitallibrary.org/terms-of-use 


\title{
Conference Committee
}

\author{
Program Track Chair
}

José M. Sasian, College of Optical Sciences, The University of Arizona (United States)

Conference Chairs

José M. Sasian, College of Optical Sciences, The University of Arizona (United States)

Richard N. Youngworth, Light Capture, Inc. (United States)

Program Committee

Sen Han, Veeco Instruments, Inc. (United States)

Chao-Wen Liang, National Central University (Taiwan)

Raymond G. Ohl IV, NASA Goddard Space Flight Center (United States)

Robert E. Parks, Optical Perspectives Group, LLC (United States) and College of Optical Sciences, The University of Arizona (United States)

Mitchell C. Ruda, Ruda and Associates, Inc. (United States)

David V. Wick, Sandia National Laboratories (United States)

\section{Session Chairs}

1 Tolerancing Optical Systems

Sen Han, Veeco Metrology Inc. (United States)

José M. Sasian, College of Optical Sciences, The University of Arizona (United States)

2 Alignment Methodology and Theory

Chao-Wen Liang, National Central University (Taiwan)

Mitchell C. Ruda, Ruda and Associates, Inc. (United States)

3 Instrument and System Alignment

Robert E. Parks, Optical Perspectives Group, LLC (United States) and

College of Optical Sciences, The University of Arizona (United States)

David V. Wick, Sandia National Laboratories (United States)

$4 \quad$ Alignment Devices, Metrology, and Fabrication

Maria D. Nowak, NASA Goddard Space Flight Center (United States)

Richard N. Youngworth, Light Capture, Inc. (United States) 
Downloaded From: https://www.spiedigitallibrary.org/conference-proceedings-of-spie on 25 Apr 2023

Terms of Use: https://www.spiedigitallibrary.org/terms-of-use 


\section{Introduction}

This is the second year that the Optical Systems Alignment and Tolerancing Conference at the SPIE Optics and Photonics Symposium has been offered. The conference this year has again been a success, with strong papers and presentations on a wide variety of topics.

The topics of tolerancing and alignment continue to play crucial roles in the development and production of optical systems. The topics are closely related and very timely as current technology is forging ahead with new methods, novel systems, and increasingly challenging requirements for a number of applications. Tolerancing and alignment are growing topics that will continue to play key roles for the success of such systems.

The Optical Systems Alignment and Tolerancing Conference intends to provide a forum where past and current knowledge about optical alignment and tolerancing is discussed. Topics include methods, applications, algorithms, and hardware related to alignment and tolerancing. In this second year, we have continued to have a variety of papers from traditional applications, mathematics, and methods, to fundamental properties of light and physical optics phenomena. The conference continued its perceived useful value with positive feedback from the audience. The reader can browse and read the papers in this volume to benefit from the expertise brought to bear by the authors. We thank everyone who has made this conference a success in its second year: the authors, audience, committee, and SPIE.

Next year we will add the topic of verification, which is essential for many types of systems. Verification of optical system performance and methodologies is also a subject closely related to alignment and tolerancing. Hence, it fits well with the current program and deserves a place in the conference. Please look for Optical Systems Alignment, Tolerancing, and Verification Conferences in the future. We look forward to next year's conference being a continued success.

José M. Sasian Richard N. Youngworth 
Downloaded From: https://www.spiedigitallibrary.org/conference-proceedings-of-spie on 25 Apr 2023

Terms of Use: https://www.spiedigitallibrary.org/terms-of-use 